\title{
Values of Selected Biochemical and Mineral Metabolism Indicators in Feathered Game
}

\author{
Pavel Suchý, Eva Straková, Leo Kroupa, Ladislav Steinhauser, Ivan Herzig
}

University of Veterinary and Pharmaceutical Science, Brno, Czech Republic

Faculty of Veterinary Hygiene and Ecology, Department of Nutrition, Animal Husbandry and Animal Hygiene

\author{
Received November 9, 2009 \\ Accepted June 15, 2010
}

\begin{abstract}
The present paper extends the current knowledge of biochemical and mineral profiles in selected species of feathered game such as helmeted guineafowl (Numida meleagris), common pheasant (Phasianus colchicus), Japanese quail (Coturnix coturnix japonica), chukar (Alectoris chucar), grey partridge (Perdix perdix) and wild turkey (Meleagris gallopavo) reared in the Czech Republic and throughout Europe. The work evaluates potential interspecies differences among the values and compares the findings with the results reported for related domesticated species of birds. Indicators investigated in the individual species of feathered game such as total protein (TP), glucose (GLU), total cholesterol (CHOL), triacylglycerides (TAG), uric acid (UA), alanine aminotransferase (ALT) and $\mathrm{Ca}, \mathrm{P}, \mathrm{Mg}, \mathrm{Na}, \mathrm{K}, \mathrm{Cl}$ varied in ranges typical for layers and broiler chickens. Except for wild turkey where mineral metabolism values reached or even exceeded the upper limit of the physiological range, which may indicate a specific interspecies difference. However, with regard to the wide physiological range of biochemical indicators in the blood of birds, significant $(P \leq 0.05)$ and highly significant $(P \leq 0.01)$ differences in most mean values for the monitored indicators can not be evaluated as interspecies differences.
\end{abstract}

Blood chemistry, helmeted guineafowl, common pheasant, japanese quail, chukar, grey partridge, wild turkey

The monitoring of biochemical indicators in blood samples from poultry is now a routine part of experimental papers in the area of veterinary medicine and animal husbandry. However, there is still a lack of information on the biochemical profile in feathered game reared in European conditions. Sporadic papers report on the assay of biochemical indicators in domesticated birds, particularly in layers and broilers, to show potential metabolic changes of different origin in a variety of experiments that focus on different objectives. The values of blood indicators are affected by many factors such as genotype, age, physiological condition, gender, diet, micro- and macro-climatic conditions, the method of rearing, season, and pathological factors. In addition, the collection samples of biological material and the methods of laboratory analysis also play an important role (Meluzzi et al. 1992). Partial results of biochemical screening in gallinaceous poultry (the order Galliformes), namely hens, are reported in papers by Jeřábek et al. (1993), Suchý et al. (2004) and Tůmová et al. (2004), or in broiler chickens by Meluzzi et al. (1992), Straková et al. (1993), Itoh et al. (1995) and others. However, similar data in feathered game is only sporadic. Some findings were reported in wild turkey by Bounous et al. (2000) or in common pheasant by Suchý et al. (2007).

The main objective of this work was to investigate selected biochemical indicators in order to gain deeper insight into the metabolic and mineral profiles of six species of feathered game, and assess potential interspecies differences.

\section{Material and Methods}

Animals and procedures

Biochemical and mineral profiles were studied in six species of feathered game: helmeted guineafowl (Numida meleagris), common pheasant (Phasianus colchicus), Japanese quail (Coturnix coturnix japonica), chukar

Address for correspondence:

Prof. MVDr. Ing. Pavel Suchý, CSc.

University of Veterinary and Pharmaceutical Sciences Brno, Palackého 1-3,

61242 Brno, Czech Republic

Czech Republic
Phone: +420541562670

Fax: +420 541562675

E-mail: suchyp@vfu.cz

http://www.vfu.cz/acta-vet/actavet.htm 
(Alectoris chucar), grey partridge (Perdix perdix) and wild turkey (Meleagris gallopavo). The birds were reared in aviaries in the accredited enclosure for the rearing of feathered game owned by the University of Veterinary and Pharmaceutical Sciences Brno in controlled conditions, using identical procedures and the same nutrition content provided by the complete feeding mixture intended for laying pheasant hens (manufactured by ADW Agro, a.s. Krahulov). One kilogram of the feed mixture contained $135 \mathrm{~g}$ of water, $145 \mathrm{~g}$ of crude protein $(\mathrm{N} \times$ $6.25), 39 \mathrm{~g}$ of fat, $27 \mathrm{~g}$ of fibre, $98 \mathrm{~g}$ of ash, $3.4 \mathrm{~g}$ of methionine, $15.5 \mathrm{mg}$ of copper, $65.0 \mathrm{mg}$ of vitamin $\mathrm{E}$ (alphatocopherol), 15,276 IU of vitamin A, 3,000 IU of vitamin D3, 5500.41 EXU of endo-1,4- $\beta$-xylanase, $9.0 \mathrm{mg}$ of butylhydroxytoluene (BHT) and $1.20 \mathrm{mg}$ of butylhydroxyanisole (BHA).

\section{Biochemical analysis}

Single blood samples were collected in February from sexually mature birds (10 months of age) hatched and reared in the previous year that were intended for reproduction. Ten clinically healthy individuals from each species $(5 q$ and 5 ) were subjected to the collection of blood samples by the puncture of vena basilica; blood samples were placed in heparinized test tubes. Blood plasma was analysed for the following selected biochemical and mineral metabolism indicators: total protein (TP), glucose (GLU), total cholesterol (CHOL), triacylglycerides (TAG), uric acid (UA), alanine aminotransferase (ALT) and $\mathrm{Ca}, \mathrm{P}, \mathrm{Mg}, \mathrm{Na}, \mathrm{K}, \mathrm{Cl}$. Biochemical indicators were determined using the biochemical analyzer with commercial diagnostic kits whereas mineral substances were determined using AAS.

\section{Statistical evaluation}

The results were processed by mathematical Cobas EMira (Hoffman, La Roche, Switzerland) and statistical methods using the statistical programme Unistat 5.6 (2005); the mean values and their differences were evaluated by multiple comparison using the Tukey-HSD test, at a level of significance being $P \leq 0.01$ and $P \leq 0.05$. Each indicator is presented by the mean value $(\mathrm{x})$ and standard deviation $( \pm \mathrm{SD})$.

\section{Results and Discussion}

The mean values of total protein (TP) in six monitored species of feathered game ranged from $34.00 \mathrm{~g} / 1$ (Japanese quail) to $64.00 \mathrm{~g} / 1$ (wild turkey) (Table 1). When compared to the mean TP value found in wild turkey, the mean TP values in individual species showed significant differences $(P \leq 0.01)$. When the values of TP are compared with a reference range for broiler chickens $(25.80$ - $52.20 \mathrm{~g} / \mathrm{l})$ reported by Meluzzi et al. (1992), it is evident that except for wild turkey (which is also an exception in our set), the TP values in other monitored species fall in the above-mentioned range. Generally, the values of TP increase with age as documented by the results reported by a number of authors, e.g. Franchini et al. (1990), Straková et al. (1994) (33.08 - 49.38 g/l).

The mean values of plasma glucose (GLU) ranged from $17.98 \mathrm{mmol} / 1$ (wild turkey) to

Table 1. Mean values of selected biochemical indicators $(x \pm S D)$ in blood plasma in the monitored species of feathered game

\begin{tabular}{|c|c|c|c|c|c|c|}
\hline Species & $\begin{array}{l}\mathrm{TP} \\
\mathrm{g} / 1\end{array}$ & $\begin{array}{c}\text { GLU } \\
\mathrm{mmol} / 1\end{array}$ & $\begin{array}{l}\mathrm{CHOL} \\
\mathrm{mmol} / 1\end{array}$ & $\begin{array}{c}\mathrm{TAG} \\
\mathrm{mmol} / 1\end{array}$ & $\begin{array}{c}\mathrm{UA} \\
\mu \mathrm{mol} / 1\end{array}$ & $\begin{array}{c}\text { ALT } \\
\mu \mathrm{kat} / \mathrm{l}\end{array}$ \\
\hline $\begin{array}{l}\text { Helmeted guineafowl } \\
\text { (Numida meleagris) }\end{array}$ & $\begin{array}{l}45.800^{\mathrm{B}, \mathrm{C}} \\
\pm 5.145\end{array}$ & $\begin{array}{l}18.650 \\
\pm 2.275 \\
\end{array}$ & $\begin{array}{l}3.600 \\
\pm 0.478 \\
\end{array}$ & $\begin{array}{l}1.210 \\
\pm 0.383\end{array}$ & $\begin{array}{l}302.900 \\
\pm 95.670 \\
\end{array}$ & $\begin{array}{l}0.108 \\
\pm 0.057\end{array}$ \\
\hline $\begin{array}{l}\text { Common pheasant } \\
\text { (Phasianus colchicus) }\end{array}$ & $\begin{array}{l}49.200^{\mathrm{B}, \mathrm{C}} \\
\pm 6.800 \\
\end{array}$ & $\begin{array}{l}20.080 \\
\pm 1.870 \\
\end{array}$ & $\begin{array}{l}3.880 \\
\pm 1.0750 \\
\end{array}$ & $\begin{array}{l}3.11 \\
\pm 2.828 \\
\end{array}$ & $\begin{array}{l}117.600^{\mathrm{B}, \mathrm{D}} \\
\pm 87.920 \\
\end{array}$ & $\begin{array}{l}0.292 \\
\pm 0.041 \\
\end{array}$ \\
\hline $\begin{array}{l}\text { Japanese quail } \\
\text { (Coturnix coturnix } \\
\text { Japonica) }\end{array}$ & $\begin{array}{l}34.000^{\mathrm{B}, \mathrm{D}} \\
\pm 3.791\end{array}$ & $\begin{array}{l}18.320 \\
\pm 1.385\end{array}$ & $\begin{array}{l}5.000^{\mathrm{A}} \\
\pm 1.799\end{array}$ & $\begin{array}{l}1.820 \\
\pm 0.614\end{array}$ & $\begin{array}{l}403.800^{\mathrm{B}, \mathrm{C}, \mathrm{a}} \\
\pm 155.370\end{array}$ & $\begin{array}{l}0.070^{\mathrm{b}} \\
\pm 0.000\end{array}$ \\
\hline $\begin{array}{l}\text { Chukar } \\
\text { (Alectoris chucar) }\end{array}$ & $\begin{array}{l}45.700^{\mathrm{B}, \mathrm{C}} \\
\pm 4.620 \\
\end{array}$ & $\begin{array}{l}20.040 \\
\pm 1.702 \\
\end{array}$ & $\begin{array}{l}4.220^{\mathrm{a}} \\
\pm 0.694 \\
\end{array}$ & $\begin{array}{l}2.110 \\
\pm 0.600 \\
\end{array}$ & $\begin{array}{l}206.500^{\mathrm{B}, \mathrm{D}} \\
\pm 56.890 \\
\end{array}$ & $\begin{array}{l}0.097 \\
\pm 0.039 \\
\end{array}$ \\
\hline $\begin{array}{l}\text { Grey partridge } \\
\text { (Perdix perdix) }\end{array}$ & $\begin{array}{l}45.600^{\mathrm{B}, \mathrm{C}} \\
\pm 7.086 \\
\end{array}$ & $\begin{array}{l}19.260 \\
\pm 2.000 \\
\end{array}$ & $\begin{array}{l}3.270^{\mathrm{B}} \\
\pm 0.797 \\
\end{array}$ & $\begin{array}{l}1.390 \\
\pm 0.544 \\
\end{array}$ & $\begin{array}{l}439.600^{\mathrm{A}} \\
\pm 166.510 \\
\end{array}$ & $\begin{array}{l}0.3100^{2} \\
\pm 0.069 \\
\end{array}$ \\
\hline $\begin{array}{l}\text { Wild turkey } \\
\text { (Meleagris gallopavo) }\end{array}$ & $\begin{array}{l}64.000^{\mathrm{A}} \\
\pm 9.401\end{array}$ & $\begin{array}{l}17.980 \\
\pm 1.566\end{array}$ & $\begin{array}{l}2.680^{\mathrm{Bb}} \\
\pm 1.178\end{array}$ & $\begin{array}{l}5.930 \\
\pm 8.520\end{array}$ & $\begin{array}{l}228.700^{\mathrm{B}, \mathrm{b}} \\
\pm 98.270\end{array}$ & $\begin{array}{l}0.129 \\
\pm 0.046\end{array}$ \\
\hline
\end{tabular}

${ }^{\mathrm{a}: \mathrm{b}}$ means in the same row followed by different superscript differ $(P \leq 0.05)$

A:B, C:D means in the same row followed by different superscript differ $(P \leq 0.01)$ 
$20.08 \mathrm{mmol} / 1$ (common pheasant); no significant differences were found and the values did not differ greatly from those found during the rearing and laying period in Japanese quail by Straková et al. (1994) (15.76-20.80 mmol/l).

The lowest concentration of cholesterol (CHOL) was detected in wild turkey $(2.68 \mathrm{mmol} / 1)$ while the highest concentration of cholesterol was found in Japanese quail $(5.00 \mathrm{mmol} / 1)$. Reported reference values for CHOL in broilers range from 2.20 to $4.99 \mathrm{mmol} / 1$ (Meluzzi et al. 1992). According to Suchý et al. (1999) the mean concentration of CHOL in layers during the laying period was $4.51 \mathrm{mmol} / 1$. The values found in the feathered game monitored in our experiment are in agreement with those reported in broilers. Significant differences $(P \leq 0.01)$ were confirmed between the average values found in Japanese quail, wild turkey, chukar, and grey partridge.

Non-significance of differences in the mean values of TAG is due to their relatively high variability. The lowest value $(1.21 \mathrm{mmol} / 1)$ was found in helmeted guineafowl while the highest value was detected in wild turkey $(5.93 \mathrm{mmol})$; this value is outside the range of mean values observed in other species and fails to fall in the range of 5.02-18.92 $\mathrm{mmol} / \mathrm{l}$ reported by Meluzzi et al. (1992). Tůmová et al. (2004) reported the mean value of $3.47 \mathrm{mmol} / \mathrm{l}$. Other authors point out the differences in the concentrations of CHOL and TAG in different hybrids, depending on gender (higher in males as compared to females) and age where the concentration of CHOL decreases and the concentration of TAG increases (Meluzzi et al. 1992; Straková et al. 1993).

The concentration of uric acid (UA) varied in a range from $117.60 \mu \mathrm{mol} / 1$ (common pheasant) to $439.60 \mu \mathrm{mol} / 1$ (grey partridge). No comparable data for these values were found in literature. The values of ALT ranged from 0.07 to $0.31 \mu \mathrm{kat} / 1$ (Japanese quail and grey partridge). Straková et al. (1993) reported the activities of ALT in blood plasma from broiler chickens ranging from 0.90 to $1.16 \mu \mathrm{kat} / \mathrm{l}$, Borsa et al. (2006) found the values ranging from 0.11 to $0.43 \mu \mathrm{kat} / 1$ in broilers in the course of feeding, which is in a good agreement with ALT values found in the monitored feathered game.

Except for a few cases, the concentrations of individual elements (Table 2) ranged in relatively narrow intervals. The lowest concentration of calcium was found in Japanese quail $(2.29 \mathrm{mmol} / \mathrm{l})$ while the highest concentration of calcium was found in wild turkey (3.72 mmol/l). The concentrations of phosphorus ranged from 1.72 to $2.29 \mathrm{mmol} / \mathrm{l}$,

Table 2. Mean values $(\mathrm{x} \pm \mathrm{SD})$ of selected macro- and micro-elements in blood plasma in monitored feathered game

\begin{tabular}{|c|c|c|c|c|c|c|}
\hline Species & $\begin{array}{c}\mathrm{Ca} \\
\mathrm{mmol} / 1\end{array}$ & $\begin{array}{c}\mathrm{P} \\
\mathrm{mmol} / 1\end{array}$ & $\begin{array}{c}\mathrm{Mg} \\
\mathrm{mmol} / \mathrm{l}\end{array}$ & $\begin{array}{c}\mathrm{Na} \\
\mathrm{mmol} / 1\end{array}$ & $\underset{\mathrm{mmol} / 1}{\mathrm{~K}}$ & $\begin{array}{c}\mathrm{Cl} \\
\mathrm{mmol} / 1\end{array}$ \\
\hline $\begin{array}{l}\text { Helmeted guineafowl } \\
\text { (Numida meleagris) }\end{array}$ & $\begin{array}{l}2.600^{\mathrm{B}} \\
\pm 0.377 \\
\end{array}$ & $\begin{array}{l}1.720 \\
\pm 0.380 \\
\end{array}$ & $\begin{array}{l}0.930^{\mathrm{B}} \\
\pm 0.094 \\
\end{array}$ & $\begin{array}{l}140.900^{\mathrm{b}} \\
\pm 6.510 \\
\end{array}$ & $\begin{array}{l}3.860^{\mathrm{A}, \mathrm{a}} \\
\pm 0.962 \\
\end{array}$ & $\begin{array}{l}103.600 \\
\pm 1.820 \\
\end{array}$ \\
\hline $\begin{array}{l}\text { Common pheasant } \\
\text { (Phasianus colchicus) }\end{array}$ & $\begin{array}{l}2.690^{\mathrm{B}} \\
\pm 0.573\end{array}$ & $\begin{array}{l}1.750 \\
\pm 0.610\end{array}$ & $\begin{array}{l}0.930^{\mathrm{B}} \\
\pm 0.136\end{array}$ & $\begin{array}{l}150.400^{\mathrm{a}} \\
\pm 8.584\end{array}$ & $\begin{array}{l}3.250 \\
\pm 1.150\end{array}$ & $\begin{array}{l}105.800^{\mathrm{a}} \\
\pm 2.120\end{array}$ \\
\hline $\begin{array}{l}\text { Japanese quail } \\
\text { (Coturnix coturnix } \\
\text { Japonica) }\end{array}$ & $\begin{array}{l}2.290^{\mathrm{B}} \\
\pm 0.189\end{array}$ & $\begin{array}{l}2.150 \\
\pm 0.538\end{array}$ & $\begin{array}{l}1.280^{\mathrm{A}, \mathrm{a}} \\
\pm 0.356\end{array}$ & $\begin{array}{l}142.600 \\
\pm 8.547\end{array}$ & $\begin{array}{l}2.400^{\mathrm{B}} \\
\pm 0.756\end{array}$ & $\begin{array}{l}99.600^{\mathrm{B}, \mathrm{b}} \\
\pm 6.780\end{array}$ \\
\hline $\begin{array}{l}\text { Chukar } \\
\text { (Alectoris chucar) }\end{array}$ & $\begin{array}{l}2.300^{\mathrm{B}} \\
\pm 0.177 \\
\end{array}$ & $\begin{array}{l}1.990 \\
\pm 0.436 \\
\end{array}$ & $\begin{array}{l}0.950^{\mathrm{B}} \\
\pm 0.063 \\
\end{array}$ & $\begin{array}{l}144.900 \\
\pm 6.536 \\
\end{array}$ & $\begin{array}{l}2.790^{\mathrm{B}, \mathrm{b}} \\
\pm 0.540 \\
\end{array}$ & $\begin{array}{l}106.000^{\mathrm{a}} \\
\pm 5.472 \\
\end{array}$ \\
\hline $\begin{array}{l}\text { Grey partridge } \\
\text { (Perdix perdix) }\end{array}$ & $\begin{array}{l}2.400^{\mathrm{B}} \\
\pm 0.201 \\
\end{array}$ & $\begin{array}{l}1.980 \\
\pm 0.750 \\
\end{array}$ & $\begin{array}{l}1.040^{\mathrm{b}} \\
\pm 0.138 \\
\end{array}$ & $\begin{array}{l}145.000 \\
\pm 6.155 \\
\end{array}$ & $\begin{array}{l}2.700^{\mathrm{B}, \mathrm{b}} \\
\pm 0.650 \\
\end{array}$ & $\begin{array}{l}105.200 \\
\pm 4.410 \\
\end{array}$ \\
\hline $\begin{array}{l}\text { Wild turkey } \\
\text { (Meleagris gallopavo) }\end{array}$ & $\begin{array}{l}3.720^{\mathrm{A}} \\
\pm 1.104\end{array}$ & $\begin{array}{l}2.290 \\
\pm 0.393\end{array}$ & $\begin{array}{l}1.020^{\mathrm{b}} \\
\pm 0.105\end{array}$ & $\begin{array}{l}151.000^{\mathrm{a}} \\
\pm 5.627\end{array}$ & $\begin{array}{l}4.180^{\mathrm{A}} \\
\pm 0.616\end{array}$ & $\begin{array}{l}108.300^{\mathrm{A}} \\
\pm 4.830\end{array}$ \\
\hline
\end{tabular}

\footnotetext{
a:b means in the same row followed by different superscript differ $(P \leq 0.05)$

${ }^{\mathrm{A}: \mathrm{B}}$ means in the same row followed by different superscript differ $(P \leq 0.01)$
} 
magnesium from 0.93 to $1.28 \mathrm{mmol} / \mathrm{l}$, sodium from 140.90 to $151.00 \mathrm{mmol} / \mathrm{l}$, potassium from 2.40 to $4.18 \mathrm{mmol} / \mathrm{l}$ and chlorine from 99.60 to $108.30 \mathrm{mmol} / \mathrm{l}$. The values found mostly fall in the ranges reported in layers or broiler chickens, except for wild turkey where the concentrations of minerals were at or above the upper limit of the reported physiological range, which may indicate some species-related distinction. Due to the high variability, significant $(P \leq 0.05)$ to highly significant $(P \leq 0.01)$ differences between the mean values cannot be evaluated as species-related differences.

The present paper broadens the current knowledge of the selected indicators of biochemical and mineral profiles in major species of feathered game reared in the Czech Republic and throughout Europe. It also evaluates inter-species differences and compares them with the values reported for related domesticated species of birds.

\section{Hodnoty vybraných ukazatelů biochemického a minerálního metabolismu u pernaté zvěře}

Předložená práce doplňuje stávající znalosti o hodnotách ukazatelů biochemického a minerálního profilu vybraných druhů pernaté zvěře, chované v našich a evropských podmínkách: perličky obecné (Numida meleagris), bažanta obecného (Phasianus colchicus), křepelky japonské (Coturnix coturnix japonica), orebice čukar (Alectoris chucar), koroptve polní (Perdix perdix) a krocana divokého (Meleagris gallopavo). Práce posuzuje, zda existují mezidruhové rozdíly nalezených hodnot a provádí jejich porovnání s hodnotami uváděnými u př́buzných domestikovaných druhů ptáků. Nalezené hodnoty u jednotlivých druhů sledované pernaté zvěře celkový protein, glukosa, cholesterol, triacylglyceridy, kyselina močová, alanin aminotransferasa (ALT) a $\mathrm{Ca}, \mathrm{P}, \mathrm{Mg}, \mathrm{Na}, \mathrm{K}, \mathrm{Cl}$ se většinou pohybovaly v rozmezích, která jsou tradována u nosnic, resp. brojlerových kuřat. Výjimkou je krocan divoký, u kterého se nalezené hodnoty minerálního metabolismu pohybovaly při, resp. nad horní hranicí udávaného fyziologického rozmezí, což naznačuje jistou druhovou odlišnost. U většiny průměrných hodnot sledovaných ukazatelů, významné $(P \leq 0,05)$ až vysoce významné $(P \leq 0,01)$ rozdíly, vzhledem k širokému fyziologickému rozmezí biochemických ukazatelů krve ptáků, nelze považovat za rozdíly mezidruhové.

\section{Acknowledgements}

Financial support from the Ministry of Education, Youth, and Sports of the Czech Republic (Grant No MSMT 6215712402) is gratefully acknowledged.

\section{References}

Borsa A, Kohayagawa A, Boretti LP, Saito ME, Kuibida K 2006: Serum levels of hepatic enzyme function in clinically healthy broiler chickens. Arq Bras Med Vet Zootec 55: 675-677

Bounous DI, Wyatt RD, Gibbs PS, Gilburn JV, Quist CF 2000: Normal haematologic and serum biochemical reference for juvenile wild turkeys. J Wildl Dis 36: 393-396

Itoh N, Moritsu Y, Ichikawa S 1995: Comparison of blood chemical values of Japanese quail, White Leghorns and broiler chickens. J Vet Med Jpn 48: 97-101

Jeřábek S, Suchý P, Illek J, Straková E, Zelenka J 1993: Haematological and biochemical parameters of the blood of hens with damaged and integral shells. Živoč Výr 38: 145-151

Meluzzi A, Promiceri G, Giordani R, Fabrik G 1992: Determination of blood constituents reference values in broilers. Poultry Sci 71: 337-345

Straková E, Suchý P, Klecker D 1993: Changes in haematological and biochemical characteristics of blood of broilers during fattening. Živoč Výr 38: 725-734

Straková E, Suchý P, Klecker D, Illek J 1994: Haematological and biochemical indicators of the blood in Japanese quail during nursing and laying periods. Živoč Výr 39: 409-420

Suchý P, Straková E, Jarka B, Thiemel J, Večerek V 2004: Differences between metabolic profiles of egg-type and meat-type hybrid hens. Czech J Anim Sci 49: 323-328

Suchý P, Bedaňová I, Večerek V, Voslářová E, Pištěková V, Chloupek P, Vitula F 2007: Effects of transport stress and floor space reduction on selected biochemical indices in common pheasant (Phasianus colchicus). Arch Geflugelkd 71: 56-61

Tůmová E, Hartlová H, Ledvinka Z, Fučíková A 2004: The effect of digitonin on egg quality, cholesterol content in eggs, biochemical and haematological parameters in laying hens. Czech J Anim Sci 49: 33-37 